\title{
LEADERSHIP FLAWS IN 2 SAMUEL 11: LESSONS FOR AFRICAN LEADERS
}

\author{
Ohaeri Nnaemeka Ndubuwa* \\ http://dx.doi.org/10.4314/og.v15i1.1s
}

\begin{abstract}
Flaws in leadership are as old as man but in contrast to Divine purpose for humanity. The good intention of the Creator was for human Beings to lead and enjoy all creatures on earth, but human deviation from Divine instruction flawed that leadership mandate and ushered suffering to human race. Similarly, the high rate of moral decadence, insecurity, insurgency, poverty, and political instability in Africa have recently gained global attention and shock, considering the wealth of human and natural resources endowed. Scholars had blamed African leaders for underdevelopment due to corruption whereas inadequate effort had been exacted on theological lessons from the Old Testament to salvage Africa from the menace. This paper employed a historical-critical method to examine the leadership flaws in 2 Samuel 11, and apply same to African context, with the aim of elucidating the causes and effects of leadership failures in governance. The paper discovered that leadership flaws are not spontaneous but evolve from untamed sporadic dispositions of inward indiscipline that manifest in form of lust, hypocrisy, conspiracy, assassination, promiscuity, hubris, cupidity and other social vices. The attitude of African leaders, in recent times, have hampered the democratic process in governance thereby giving room to ethnic divisions, imposition pattern of leadership selection process, inequitable resource control, economic backwardness and mediocrity in education amongst others. This paper therefore recommended self-discipline, fear of God, dialogue, equitable resource control, religious reproof, empathy, checks and balances for the minimization of leadership fallibilities and maximization of good governance in African Society.
\end{abstract}

Keywords: Leadership, Flaws, Africa, Lessons 


\section{Introduction}

Leadership as an integral part of every organization or nation is a determinant of her goal accomplishment. The peace and development of any nation depend on the commitment of leaders at all levels ranging from the family unit, religious institutions, and traditional settings to national politics. On the other hand, leadership flaws affect the citizenry and national development adversely. Leadership, therefore, is a catalyst that kindles the maximization of individual potentialities, human and natural resources of a nation for sustainable development.

The indispensability of leadership is evident in the Old Testament narratives beginning from the accounts of creation, through patriarchal narratives, mosaic era in the exodus event, the conquest and period of monarchy in Ancient Israel. The remarkable achievements of great biblical leaders were not without flaws, hence, the consequential wrath of God that eventually led the Israelites to exile despite their divine election, deliverance and covenant. The book of Samuel recounts two significant changes in the life of Israel. First Israel moves from theocracy to monarchy; second, under David's leadership, Israel changes from a loose confederation of twelve tribes to a centralized state with a well-organized administration. Such changes have important consequences in the life of the people and as such determine their future.

Africa has undergone similar changes as she has experienced slave trade, colonization, rise of independent autocratic states and democratization. It is instructive to note that the leadership flaws of Saul; the first monarch of Israel necessitated his rejection and the divine choice of David as his successor. Unfortunately, David's leadership failures in 2 Samuel 11 flawed his great accomplishments and brought untold consequences to his family and entire nation of Israel culminating to divided kingdom and exilic experience.

In the same vein, Africa is undergoing hectic experience of dwindling economy, insurgency, political instability and underdevelopment, despite her endowment in human and natural resources. This paper, therefore, aims at examining leadership flaws in Africa as the reason behind her plight, with lessons from 2 Samuel 11. The work is not oblivious of some scholastic recommendations for curbing leadership failures in Africa through 
Ndubuwa: Leadership Flaws in 2 Samuel 11: Lessons for African Leaders

accountability, rather it builds on the existing studies to proffer succor from theological perspectives. Lessons from 2 Samuel 11 will contribute to knowledge and also help to minimize leadership flaws in African society for peaceful coexistence and sustainable development.

\section{Concept of Leadership}

Scholars have conceived leadership in different ways based on their fields of study and modes of perception. Treat (1989) views leadership as a process of guiding, directing and commanding others to achieve a desired goal. Leadership makes the difference in any organization since the leaders know the way to accomplish the vision and then lead others to actualize it. Munroe (1997) asserts that an effective leadership is attained by the good character of the leaders. In his word "true leadership cannot be divorced from the basic qualities that produce good character" (p. 48). Leadership is built by good character which comprises natural and spiritual qualities such as fear of God, wisdom, humility, decisiveness, empathy and so on. Leadership is not about getting power and position but becoming a servant. This means that any leadership in which the leaders only aspire to gain power and position may not be effective but will center on selfish interests that retards the growth and development of the organization. Maxwell (2007) opines that Leadership is the art of creating a good path for others to follow. It involves putting the needs of others above one's need. For Souza (2010) leadership should be exemplary.

Goleman, Boyatzis and Mckee (2004) assert that the fundamental task of leadership that gets result is to prime good feeling in the followers. Blanchard and Hodges (2003) aver that good leadership begins in the heart and proceeds to the head, to the hands and then to habits. According to Weisenger (1998) the inner life or heart of the leader is very important because change does not happen without a leader. And every organization or church movement rises and falls on its leadership.

Iruoma (2003) classifies leadership into three basic styles namely: the autocratic, democratic and Laissez-faire leadership styles. The autocratic also known as authoritarian leadership is a style in which the leader has the complete power to lead the people by lording it over the followers in decision making and impose them 
with no feeling of responsibility or accountability. Democratic leadership also called participatory leadership style is one which the leader calls on the members to identify limits, explore situation and make decisions by allowing participation in every aspect of the leadership. Whereas in Laissez-faire style of leadership the leader can communicate goals and guidelines or sometimes allows the followers to either meet with these goals according to their ability, willingness or directives. Here the leader acts on the total suggestions of individuals and allows the members to do what they feel is right. Nobody is rebuked or corrected since there are no specific guidelines. Furthermore, in transformational style of leadership, teamwork is encouraged as the means for getting the best for the organization.

\section{A Hermeneutical Investigation of 2 Samuel 11 in the light of Leadership Flaws}

The hermeneutical investigation focuses on the historical context of 2 Samuel 11 and exegetical analysis of selected verses, such as 1, 4, 15 and 27 which reveal the leadership flaws of King David.

\section{Historical Context of 2 Samuel 11}

Prior to the narrative in 1 and 2 Samuel, Israel had operated under theocratic system of Government consequent upon divine election and covenant but with human leaders as Prophets, Priests, Levites, and Judges. Theocracy is a system of government where God is the ruler who dictates the governance of the people through human-led offices as in the Old Testament. The Septuagint combined 1 and 2 Samuel with the book of Kings under the title "Kingdoms", while the Hebrew text traditionally called them Books of Samuel in recognition of the significant role of Samuel in the establishment of the monarchy. Therefore, 1 and 2 Samuel as a single book originally covers the period of the transition from the Judges through the establishment of the monarchy, with Saul and David as the first and second kings of Israel respectively according to Hill and Walton (2009). The book was proposed to have been composed about 931 BC after the reign of King Solomon while McCain (2002) suggests $1050 \mathrm{BC}$ to be the date of portions containing Samuel the principal character. 
The leadership flaws of Saul introduced David as a divine choice for the governance of Israel as a nation. David's legitimate appointment by Prophet Samuel had remarkable legacy but not without weakness. 2 Samuel 5-9 contain the achievements of King David such as his conquests and establishment of Jerusalem as the new capital city, restoration of the Ark of the Covenant from exile, formation of Davidic covenant which re-established the throne of Yahweh and David to usher the new covenantal era. In spite of David's achievements, his leadership flaws in 2 Samuel 11 jeopardized the governance of Israel with untold predicaments in the areas of family, ethnicity, security, religion, national development and leadership.

Literarily, one in a cursory glance may summarize 2 Samuel 11 as David's adultery with Bathsheba and subsequent conspiracy for the murder of her husband, Uriah. However, hermeneutical analysis through historical-critical method of the text unveils various lessons from the leadership flaws of King David and their implications to contemporary governance and national development. Greer, Hilber and Walton (2018) identify the source of the text under study within the Deuteronomistic History. The Corpus has as well produced scholastic sources such as Succession narrative, the account of the temple construction, the ark narrative, Saul's rise and fall, the rise of David, Nathan's oracle and the court history of David. Hill and Walton (2009) observe that the Succession Narrative (2 Samuel 10-20) focuses on the family of David, of which the leadership flaws in 2 Samuel 11 form the foundation of the section. Although, some scholars contend that the Succession Narrative begins with David's kindness to Mephibosheth in chapter 9, which is better suited to David's rise and successes concluding his obligation to Saul's house through his covenant with Jonathan, whereas chapter 10 deals with Israel's war with the Ammonites.

\section{Hebrew Text of 2 Samuel 11: 1, 4, $15 \& 27$}

ykiaal.M;h; taceä Ÿt[eäl. hn" $\div V^{\prime}$ 'h; tb;'Wvt.li •yhiy>w: .1 lae ${ }^{a}$ "f.yI-lK'-ta,w> AMø[i wyd"'b'[]-ta,w> •ba'Ay-ta, dwI²D" xl;äv.YIw: bveîAy dwIßd"w> hB'_r:-1[; WrcUßY"w: !AMê[; ynEåB.-ta, 'Wtxi'v.Y:w: ¿ Øil'(v'WryBi 
Ogirisi: a new journal of African studies vol. 15s 2019

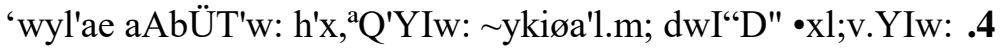
'Ht'(yBe-la, bv'T'Pw: Ht'_a'm.Jumi tv,D<Pq;t.mi ayhî̂w> HM'a $[\mathrm{i}$ bK;äv.YIw: hY"(CrIWa)-ta,

Wbåh' rmo=ale rp,SePB; bToïk.YIw: .15 'tme(w" hK'înIw> wyr"Px]a;me T,îb.v;w> hq'êz"x]h;( 'hm'x'l.Mih; ynEÜP. 'IWm-la, Hp'Ûs.a;Y:w: dwI $\div$ D" xl;’v.YIw: lb,aeah' rboæ[]Y:w: .27 rb" $\pm D " h$; [r;YEôw: !BE+ Alß dl,Teîw: hV'êail. Alå-yhiT.w:

'AtyBe-la, ‘hw")hy> ynEïy[eB. dwIßd" hf'î['-rv,a]

\section{Smooth Translation of 2 Samuel 11: 1, 4, $15 \& 27$}

Verse 1: And it happened at the turn of the year, at the time when kings go out, David sent Joab, and his servants with him, and all Israel. And they destroyed the sons of Ammon, and lay siege to Rabbah. But David remained at Jerusalem.

Verse 4: And David sent messengers and took her. And she came to him, and he lay with her. And she was purified herself from uncleanness, and she returned to her house.

Verse 15: And he wrote in the letter, saying, "Place Uriah in the front of the strongest fighting, and withdraw from him, that he may be struck, and die."

Verse 27: And the mourning time passed by. And David sent and gathered her to his house, and she became his wife, and bore a son to him. And the thing which David had done was evil in the eyes of Yahweh.

\section{Exposition of the Text in the Context of Leadership Flaws}

The key points for consideration in 2 Samuel 11:1 are the clauses $\sim \mathrm{yki}$ al.M; h; taceä Ÿt [eäl. "the time when kings go out to battle" and ¿ Øil'(v'WryBi bveîAy dwIßd"w> "But David remained at Jerusalem." Carson, Motyer and Wenham (2004) explain that David resumed his operations against Ammon in the spring, since the cessation of military enterprises in the winter months was normal in Ancient Near East. But the question is, did David necessarily need to accompany the army to war as a king since Israel's victory was sure? Israel's military exploit against the Ammonites in conquering and besieging Rabbah, the capital city must have given sense of security 
Ndubuwa: Leadership Flaws in 2 Samuel 11: Lessons for African Leaders

to the king and confidence to the powerful gallant army of Israel. So David relaxed at Jerusalem with women and children while all men in Israel went to war.

Meyer (1987) describes David's attitude as a fatal lethargy that besmirched his character because he was not on duty as a leader. His view is that Rabbah was being besieged and had not fallen yet. Therefore, the King's relaxation at home portrayed nonchalance when his soldiers were at the war front. Carson (2004) avers that a sense of ease and security here is the prelude to spiritual and moral failures. His immoral acts despite the fact that Bathsheba was a married woman were abuse of power and position. Harlow (1970) observes that King David often went to war with his army except this particular year he fell into sin (2 Samuel 10:17). Evans (2008) opines that King David's action was out of place having known that his primary assignment was to conquer the Philistine. So David neglected his primary duty as the commander in chief of the armed forces by staying at home when all Israel were at the war front. It appears that David lost his military enthusiasm, especially when Israel started gaining supremacy over their enemies. David seems to be a man of huge but fairly short-lived enthusiasms, an excellent initiator of projects, but not quite so good in maintenance mode.

Probably, David identified Joab as an excellent general and so delegated all military responsibility to him in order to concentrate on issues at home. Nice as it may sound, was David moral on domestic affairs? Or did absolute power corrupt him absolutely? Certainly not, rather his over-confidence and carelessness brought calamity to him, his family and entire nation of Israel. Therefore, first leadership flaw in the text is negligence to duty or responsibility. Apart from absconding from war as a Commander in Chief of the Armed Forces, he did not also occupy himself with government or religious functions at the palace, instead, he gave in to sleeping due to overconfidence only to wake up in the evening and started walking on the rooftop of the palace. Imagine a military leader sleeping and strolling on the rooftop of the secretariat whereas the male citizens were at the fierce war front. From there he saw Bathsheba undergoing ritual bathing in her courtyard to cleanse herself after her menstrual period. David sent for her and committed adultery with her without remorse, knowing very well that she was married to his subject. This implies that Bethsheba could have been 
Ogirisi: a new journal of African studies vol. 15s 2019

a poor woman with roofless bathroom and could not have been pregnant before David had sexual intercourse with her, of course her husband a poor Hittite was at the war fighting for God, David and Israel.

In verse 4 David's lust; greed and adultery are seen as another leadership fallibility that rendered him culprit of Bathsheba's pregnancy. The Hebrew words HM'a $[\mathrm{i}$ bK;äv.YIw: translated "and he lay with her" from the root word bK;äv" (to lie down) show that David performed sexual act which Meyer (1978) views as indiscipline in what he termed 'giving rein to selfindulgence'. For him the king's attitude was not an isolated sin but inward backsliding and indiscipline. The cankerworm takes its toll before the noble tree crashes to the ground. The unruly behavior of the king threw him into terrible and disgraceful prominence. Furthermore, arson, France, Motyer and Wenham (2004) describe this leadership weakness of David as resulting from spiritual slumber and moral failures coupled with abuse of power and position. Nevertheless, David's lust could be seen as disloyalty to God and to his own loyal follower, Uriah. The king undermined his obligations to God's law and to the citizenry just to credit his selfish interests.

Consequently, Terrein (1953) observes that David's leadership flaw in this text was not only flagrant denial of the will of God but also the ruthless exploitation of his subjects. First, this ruthless exploitation is evident in the sexual assault meted on poor Bathsheba at the climax of her menstrual cleansing, psychologically trauma and loneliness of a woman whose only companion had gone to war. The fact that the narrative did not disclose Bathsheba's opposition and struggle before or during the sexual intercourse with the King should not keep us totally obscured to the imagination of the ugly incidence, considering the psychological, environmental, physiological, philosophical and religious factors involved.

Evans (2008) imagines that Bathsheba probably might not have been a willing participant in the unprecedented adultery. There is no way of disclosing whether she was flattered by David attention or felt coerced and unable to refuse the king's command. The writer shows no judgment about her guilt but genuine grief probably points to her unwilling co-operation in verse 4. However, whether Bathsheba was willing or not makes no difference. David, a man 
Ndubuwa: Leadership Flaws in 2 Samuel 11: Lessons for African Leaders

after God's heart and the king of Israel knew very well that Bathsheba was married to Uriah, a gallant soldier. If Bathsheba was forced to sexual immorality, then she was sexually harassed and possibly raped at the peak of her menstrual cleansing. What a dehumanizing, obnoxious and felonious treatment to a poor woman.

Another exploitation of the subject seen as a major flaw in the episode is David's tactful conspiracy to assassinate innocent Uriah after impregnating his wife. On the other hand, Uriah's innocence and loyalty to duty could be seen in his refusal to go and sleep with his wife while Israel was still at the war front. He preferred to flout the king's order and persuasion to compromise even after subjected to drunkenness. This kind of loyalty is rear among African citizens and should be emulated. The King maliciously gave him his death warrant to deliver to Joab instructing the army commander to set him in the battle line and desert him to die, thus: "Place Uriah in front of the strongest fighting, and withdraw from him, that he may be struck, and die." (tme(w" hK'înIw> wyr"Px]a;me T,îb.v;w> hq'êz"x]h;( 'hm'x'l.Mih; ynEÜP. 'lWm-la, hY"(OrIWa)-ta, Wbåh'). This is lack of love for the citizenry - neither Bathsheba nor Uriah but a scheme to avert the consequential responsibility of the unwanted pregnancy. David's instructive diction thus: ynEÜP. (front of), hq'êz"x]h (strongest), hm'x'l.Mih (the fighting), T,îb.v;w> (and withdraw), wyr"Px]a;me (from him), hK'înIw> (that he be struck), tme(w (and die), demonstrates his ferocious, impious, sadistic and cruel acts against his subordinate for selfish interest. Meyer (1987) describes David's bloodletting as a fatal leadership flaw.

Evans (2008) commends the unprecedented editorial comment of the writer on the gravity of the offence, pointing out God's displeasure over David's leadership weakness in the narrative. Again, a critical look at the Hebrew words 'hw")hy> ynEïy[eB. dwIßd" hf'î['-rv,a] rb" \pm D"h; [r; YEôw: "and the thing which David had done was evil in the eyes of Yahweh" shows God's disapproval of David's unruly act as a leader. Green (1985) points out the displeasure of God in the translation of ynEïy[eB (in the eyes of) from the root word iyi[; (an eye) used anthropomorphically for God. Evans (2008) asserts:

Whether God's displeasure stemmed more from the avoidance of responsibility by remaining in Jerusalem, adultery, the murder or the 
abuse of power is not elaborated on at this stage. What is absolutely certain is that David, in spite of being king and in spite of eternal promises God had made to him, was not above the law. (p. 212).

This implies that any deviation from the provisions of the law is evil and displeases God. Harlow (1970) emphatically laments that the gravity of the king's offence was not only that he sinned by neglecting his responsibility but grossly that he led his subjects to sin, thus: He led Bathsheba to adultery, Uriah the Hittite to drug abuse or alcoholism, Joab to murder and blasphemy and his warriors to being accomplice to murder. Meyer (1987) views David's action of using Joab to assassinate Uriah as leading him to blasphemy (2 Samuel 11:15). He asserts thus:

Joab must have smiled grimly to himself when he received his master's letter. 'This king of ours can sing Psalms with the best, but I have to do his dirty work. He wants to rid himself of Uriah - I wonder why? Well, I'll help him to it. At any rate, he will not be able to talk to me about Abner!' 2 Samuel 3:27. It is an awful thing when the servants of God give the enemy such occasion to blaspheme. (p. 140). David's order to set Uriah up for execution was what Ndubuwa and Ikerionwu (2018) describe as an abuse of delegation in team leadership which results to psychological trauma in the long run.

Harlow (1970) highlights the leadership flaws of David as intentional and unintentional chain pattern of Sin against the word of God; one sin leads to another (James 1:15) thus:

Where do evil thoughts, adultery and murder come from? Matthew 15:19. He stayed at home instead of going out to fight for the Lord, (Jeremiah 48:10). He watched a woman and desired her in his heart, (Matthew 5:28). He took another man's wife in a sinful way, (Hebrew 13:4). He acted falsely to avoid the results of his sin; he called Uriah to come home, (Rev. 21:27). He made Uriah drunk, (Eph. 5:18). He told Joab to put Uriah to death, (1 John 3:15). He would not confess his but hardened his heart as if nothing had happened, (Matthew 23: 28; Rom. 2:5). (p. 95).

David did not plan to sin against God and do such wrong things to Bathsheba and Uriah but his desires and inward waywardness led him from one level of sin to another against God and humanity. 
Ndubuwa: Leadership Flaws in 2 Samuel 11: Lessons for African Leaders

\section{Leadership Flaws in Africa and Lessons from 2 Samuel 11}

The episode is instructive on the pandemic nature of leadership flaws in national retrogressions or deterioration. The tragic events of David's leadership failure devastated not only his family but also the lives of the entire Israel at long run. Adeyemo (2006) observes that this disgusting story does not appear in the Chronicles. 1 Chronicles 20:1 is similar to 2 Samuel 11:1, but the verses that follow in 1 Chronicles pick up the story at 2 Samuel 12:29-31, leaving out everything contained in 2 Samuel 11: 2-12:28. African leadership is not far-fetched in similar repulsive events. The following points are discussed for prevention and minimization of leadership fallibility in Africa: negligence of responsibility, challenges of maintaining civic values, corruption and moral decadence among leaders, insurgency, genocide and xenophobic attacks.

\section{Negligence of Responsibility in Africa}

Just like King David in 2 Samuel 11:1, African leaders have betrayed the trust of the citizens due to corruption, nepotism, egoism and abuse of power for personal interests. Their self-interest and alienation to the citizenry are similar to the colonial masters' approach. African countries are still bewildered with political and economic depression consequent upon self-inflicted slavery; yet blames against imperialism and neo-colonialism are the song of contemporary leaders. It is obvious that the colonial masters have gone but oversight of internal factors and weakness has disrobed us exemplary leadership style, thereby plunging Africans into pathetic catastrophe of self-slavery over the years.

Negligence of duty is a cankerworm that has eaten deep the fabrics of African leaders and citizens. Energy is exacted on selfish activities at the expense of ideal official obligations that will benefit the entire populace. It is no longer news that most African contemporary leaders imitate their military counterparts and blame their predecessors for corruption, economic mismanagement, and high cost of living as a camouflage of their incompetence and myopic leadership. They, rather, present loquacious manifestoes for multiple tenure or life-time governance rotated around the same unscrupulous cabals. The assessment of Adegbua and Adejuwon (2012) on selected African states shows that countries like Nigeria, Zaire, Malawi, Zimbabwe, Zambia, Kenya, Ghana, Liberia and 
Ogirisi: a new journal of African studies vol. 15s 2019

Central-African Republic have had autocratic leadership in the garb of democracy. Their leaders exploited and enslaved the citizens in various ways with hesitations in handing over power to the incumbents even after the expiration of their extra tenures.

\section{Challenges of maintaining Civic Values}

Ikerionwu and Ndubuwa (2019) opine that character for purposeful citizenship and statesmanship is a virtue that should be transferred from leaders to the citizens. That is how civic values can be maintained for the development of Nigerian - African society. The immoral vices of African youths are the product of bad leadership because the citizens imitate the conduct of their leaders to reproduce same when leadership opportunities come their ways. It is difficult to be patriotic citizens when the conditions for civic values are bastardized by those in power who supposed to lead exemplary lives. For instance, what kind of leaders would Joab and other conspirators of Uriah become when the murder of a fellow gallant soldier was masterminded by their leader, David? Is that not an automatic license to violate civic values with no respect to sanctity of life? Similar situations are not implausible in African society. Infringement of human rights leads to non-observance of civic values and proliferation of chaos in the society. Therefore, satisfactory exemplary leadership with accountability will promote the observance of civic values in Africa. For instance, if those in power obey traffic rules, the citizens will follow suit.

\section{Corruption and Moral Decadence among African Leaders}

The episode reveals that while walking on the roof of his house, the king was seduced by Bathsheba's beauty as she was bathing after her menstrual period. No dialogue is recorded between David and Bathsheba, and there is no indication of love. The liaison appears to be one-sided, with David exercising his power in a corrupt way, in order to please himself. Bathsheba's situation reflects the plight of many African women who are subjected to the whims of those who hold power or have weapons. In fact, the verb used in Hebrew h'x, ${ }^{a} Q$ 'YIw: (and took her, from the root verb xq; l' 'to take') to David's command could be interpreted as "take by Force," strongly suggesting that Bathsheba was virtually abducted. In Many regions of Africa, married women and young girls are similarly taken by 
Ndubuwa: Leadership Flaws in 2 Samuel 11: Lessons for African Leaders

force and often used as sex slaves by those who feel oppressed by the government as a way of retaliation to bad leadership. Moreover, many women in Africa die of sexually transmitted diseases (STDs) because they are given no choice about sexual relations, and cannot insist that their partners be faithful to them alone, or even ask for protection. The first time Bathsheba's voice was heard was when she sent words to the king that she had conceived (2 Samuel 11:5). In Hebrew, this message is only two words long ykinO*a' hr"îh' (I am pregnant).

Moral decadence breeds various kinds of corruption which has affected all strata of government in Africa including the religious sectors. Economically, Nigeria was rated number 138 corrupt country in the world in the 2016 corruption perception index of Transparency International. All these are occasioned by leadership loopholes in accountability. Just like there is societal corruption, ecclesiastical corruption has also eaten deep into the fabric of the religious sector. Compromise of religious leaders has given room for greed, spiritual backwardness, misappropriation of Church or religious fund, religious intolerance and commercialization of religion. Infidelity and other immoral practices indulged by some religious leaders mislead their members to doing evil. Hence, Oyeku (2019) laments on the high rate of societal and ecclesiastical corruption in Nigeria pointing out that teaching the undiluted messages of the scripture, ethics of moral uprightness and better remuneration will help to minimize ecclesiastical corruption of all kinds. Furthermore, Ikerionwu and Ndubuwa (2019) outline that abandonment of projects, poor roads, inadequate sanitation, erosion problems, denial of citizens' rights and non-observance of civic value are some of the effects of misapplication of leadership and reciprocity in Nigeria. However, Justice, equity, good economic management and fairness in handling human and natural resources will help develop Africa.

\section{Insurgency in Africa}

Carson, Motyer and Wenham (2004) frankly note that David's useless attempts to induce Uriah to go home and have intercourse with his wife also put him in a very bad light (2 Samuel 11:6-13). The background to this part of story is the fact that the soldiers had taken an oath at the beginning of the campaign to abstain from 
Ogirisi: a new journal of African studies vol. 15s 2019

sexual relations (1 Samuel 21:4-5). It is possible that David's suggestion to Uriah that he should wash his feet (2 Samuel 11:8) refers to a ritual that would release him from this oath. In any case, Uriah considered himself to be in active duty and showed the highest standards of moral conduct.

Similarly, the recent happenings of insurgency in Nigeria and xenophobic attacks in South Africa show the ingratitude of Africans towards themselves and other foreign nationals following the records of the apartheid. The battle against apartheid in South Africa at the inception of 1990s reduced the support of African countries including Nigeria. But it is dehumanizing and disgusting to witness such xenophobic attacks and reckless threat with utmost brutality against foreign nationals especially Nigerians in South Africa in recent times. This fight and ill-treatment against ourselves hinder peace and development consequent upon leadership flaws. Lessons should be learnt from God's displeasure on David's action against Uriah's family which could be likened to conspiracy and killings. Ucheawaji and Soyemi (2004) opine that xenophobic attacks and similar insurgency in South Africa against Nigerians and foreign nationals could be as a result of inadequate information and records management in Africa. This inadequacy and non-utilization of the available information and records could be further blamed on leadership failures towards education, information technology and implementation of policies in accordance with the constitutions. Deviation from blueprints of National Conferences has paved way for political instability, moral decadence and mediocrity in education standards, hate speeches, kidnapping, assassination, militancy, insurgency and other corrupt practices.

If the leadership flaws of David could lead to genocide at the point when Israel had already besieged Rabbah, the capital city of the Ammonites, then it is not exaggeration to allude Boko Haram Insurgency, agitation of freedom by the Indigenous People of Biafra and other religious cum ethnic crisis to the failures of African leaders at various levels. Africans should learn that these menaces do not only have immediate consequences but generational nuisance and tragedy in the society. It is unfortunate that leadership fallibilities have globally brought disrepute to Africa despite her rich human and natural resources endowment. The Postcolonial Africa is internationally unsafe for foreign investments and economic 
Ndubuwa: Leadership Flaws in 2 Samuel 11: Lessons for African Leaders

transactions due to high rate of leadership flaws at all levels of the society.

\section{Recommendation}

This paper therefore recommends that African leaders and citizens should learn to be loyal to God and humanity in order to be selfdisciplined and inculcate same to generations ahead. It is obvious the African leaders enslave the masses in various ways such as political, religious, sex and domestic slavery as noted by Sibani and Ndubuwa (2016). This paper therefore recommends that culprits of any kind of slavery in Africa should be prosecuted to serve as deterrent to others and future generations. There is need to eschew internal political slavery by reduction of abject poverty through equitable resource control and proper allocation of national revenue. Again, lopsided appointments in favour of ethnicity and religion should be discarded to avoid political instability.

Africans should emulate Uriah in patriotism to relinquish comforts offered by the King and to refute such authoritative compromise against all gimmicks. Selfishness amongst other corrupt practices should be renounced even when displayed and supported by higher authorities, like King David. Rather than exploitation, investments on human development and entrepreneurship should be encouraged in both religious and secular leadership through theological education and religious reproof as averred by Ndubuwa and Effiong (2019). Promotion of Human Rights and Sanctity of life, morality, accountability and democratization should be upheld for further prevention and reduction of leadership flaws in Africa. Nevertheless, African leaders should employ dialogue as a method of promoting peace and harmony for sustainable development.

\section{Conclusion}

This paper summits that most contemporary problems of leadership in Africa are caused internally and can only be solved by African leaders with little or no foreign assistance. Leadership imperfection is inevitable, however; controllable flaws should be prevented and minimized for impactful governance. African backwardness in politics, security and economy has been viewed as a consequence of leadership flaws. Assumption of leaders seems patriotic at the beginning but their later performance reveals their hidden motives. 
Ogirisi: a new journal of African studies vol. 15s 2019

Lessons drawn from the under-studied text show that negligence of duty, sexual immorality, kidnapping, drug abuse, assassination and misuse of power masterminded by king David are prevalent in African leadership with untold consequential deterioration in politics, economy, security and education. All hands must be on deck to reduce leadership flaws in religious and secular spheres.

*Ohaeri Nnaemeka Ndubuwa, PhD, Department of Theology, College of Arts, Wesley University Ondo, Nigeria ohaerinnaemeka@gmail.com 
Ndubuwa: Leadership Flaws in 2 Samuel 11: Lessons for African Leaders

\section{References}

Adeyemo (2006). Africa Bible Commentary. Nairobi: Paulines.

Arnold, B.T. (2005). "Books of Samuel". In Arnold B.T. \& G.M. Williamson. Dictionary of the Old Testament: Historical Books. Downers Grove, Illinois: Inter-Varsity Christian Fellowship.

Awojobi, O. P. \& T. Agboluaje (2012). Samuel's Examplary

Leadership as a Model for Theological Educators in Africa.

In WAATI Journal No. 6, 71-77.

Carson, D. A., France, R. T., Motyer J. A. \& G. J. Wenham (2004). New Bible Commentary. England: Inter-versity.

Evans, M. J. (2008). The Message of Samuel. Nottingham: InterVersity.

Goleman, D. \& B. Richard (2002). Primal Leadership. America: Harvard.

Green, J. P. (2008). The Interlinear Bible Hebrew-Greek-English. United State of America: Hendrickson.

Greer, J. S., Hilber, J. W. \& J. H. Walton (2018). Behind the Scenes of the Old Testament; Cultural, Social and Historical Contexts. Michigan: Baker Academic.

Harlow, R. E. (1970). King David Studies in 1 and 2 Samuel. Hong Kong: Everyday Publication.

Hill, A. E. \& J. W. Walton (2009). A Survey of the Old Testament. Michigan: Zondervan.

Ikerionwu, B. C. \& O. N. Ndubuwa (2019). The Irony of

Leadership, Observance of Civic Values and Application of

Reciprocity in Nigeria. In Igwebuike: An African Journal of Arts and Humanities. Vol. 5. No. 1. 25-36.

Iruoma, I. N. (2004). Church Management in Today's World. Owerri: Krison.

Maxwell, J. C. (2007). The 21 Irrefutable Laws of Leadership. Nasville: Thomas Nelson.

McCain, D. (2002). Notes on the Old Testament Introduction. Jos:

African Christian Textbooks.

Meyer, F. B. (1987). Bible Commentary. Illinois: Tyndale Home.

Ndubuwa, O. N. \& B. C. Ikerionwu (2018). Adopting Exodus 18:

13-27 as a Model for Managing Leadership Stress in Methodist Church Nigeria. In international Journal of Religion \& Human Relations. Vol. 10. No. 1. 132-171. 
Ogirisi: a new journal of African studies vol. 15s 2019

Ndubuwa, O. N. \& E. U. Effiong (2018). Theological Education and Investment in a Recessed Nigerian Economy. In In

Igwebuike: An African Journal of Arts and Humanities. Vol. 4. No. 5. 20-30.

Ndubuwa, O. N. \& E. U. Effiong (2019). Religio-Political Challenges in Nigeria's Governance: A Re-interpretation of Genesis 25:27-34. In AKSU Journal of Social and Management Sciences (AJSMS). Vol. 2. No. 1. 67-82.

Oyeku, S. K. (2019). African Christianity and Ecclesiastical Corruption: Nigeria as a study case. In A Fetschrift: African Christianity in Local and Global Contexts. Department of Religious Studies University of Ibadan. Vol. 7. 426-435.

Rudolph, W. \& K. Elliger (1997). Biblia Hebraica Stuttgartensia. Germany: Studienausgabe.

Sibani, C. M. \& O. N. Ndubuwa (2016). Biblical and Contemporary Slavery: A Religious Reflection. In SWEM Journal of Religion \& Philosophy. Vol. 6. No. 1. 45-56.

Souza, A. D. (2010). Leadership: Trilogy on Leadership Effective Management.Nairobi: Paulines.

Terrien, S. (1953). The Interpreter's Bible. Nashville: Abingdon. Treat, C. (1971). Church Management: Leading People in Church Growth. Washington: Casey.www.herald.co.zw/africasleadership-failure/ Retrieved 19/10/19. 6:28am www.https://allafrica.com/stories/201606110195.html. Retrieved on 19/10/19. 6:20am. 